among undergraduate men and women. College Student Journal, 46(1), 8898.

Tong, S.T., Van Der Heide, B., Langwell, L. \& Walther, J.B. (2008). Too much of a good thing? The relationship between number of friends and interpersonal impressions on Facebook. Journal of Computer-Mediated Communication, 13, 531-549.

Turkle, S. (1995). Life on the screen: Identity in the age of the Internet. New York: Simon \& Schuster.

Vasquez, C. (2014). The discourse of online consumer reviews. London: Bloomsbury.

Walker, K.L. (2015). Women's Communication and Language. The International Encyclopedia of Communication. Wiley Online Library. DOI: 10.1002/9781405186407.wbiecw007.pub3

Weatherall, A. (2008). Gender and Discourse. The International Encyclopedia of Communication. Wiley Online Library.

DOI: 10.1002/9781405186407.wbiecg005 


\section{Nationalism as Dystopia: A Reading of Sam Shepard's The God of Hell}

Ingy Hassan Mohamed

"This is what we're up against now. Lying, deception, manipulating the truth," asserts Sam Shepard's government agent in The God of Hell (38). Building a society based on the ideals of truth and honesty -and freedom and dignity implied in the ability to say the truth- is the cause the American government is working to achieve, as announced by this government representative in The God of Hell (2005). Yet, this is neither understood nor seen realized by the other characters in the play. In this study, I will attempt a reading of The God of Hell, focusing on the discrepancy between word and action as a dramatic representation of postSeptember 11 American policy. This policy will figure here as a factor leading to a kind of dystopia where the individual struggles to unravel an ambiguous existence, to express his needs, to assert his claims, and to develop a sense of his own value, of his own identity, a process which ends with the individual's destruction.

The action of The God of Hell takes place on a Wisconsin dairy farm where the heifer-breeding couple, Frank and Emma, has been leading a peaceful rural life. The two characters represent the typical rustic isolated life of the Midwest with which they are entirely content: "There's no tension here. We're in the country here. Everything's quiet and peaceful," Frank says, describing their life in the opening scene (18). Emma, similarly, appreciates this tranquil life where "nothing ever happens," which explains why she is "not afraid of anything" (22, 23). Establishing this picture of a utopian existence at the outset of the play is integral in underlining the impact of the government agent's appearance in the couple's life, an appearance which results in its utter disruption.

The play starts with the couple talking about an old friend of Frank's - Graig Haynes - who had disappeared for some time, and is now taking shelter in the basement of their farm house. As the action progresses, the identity of Haynes unfolds; he is a radioactive refugee from a plutonium-producing facility. Now, he is hiding from a scientific operation of making bombs. This operation is run by the government and, apparently, he has been previously involved in it. Later, the play reveals Haynes as a plutonium carrier. His appearance in Frank's and

\footnotetext{
* Assistant Professor, Department of English Language and Literature, Fauclty of Arts, Cairo University.
} 
Emma's life shatters it. Haynes is pursued by Welch, a government agent who presents himself to Frank and Emma as a salesman of "patriotic" souvenirs. In the process of arresting Haynes, Welch does not only humiliate and torture him but also causes Frank and Emma tremendous suffering, both physical and psychological. Frank is seen on stage moving in pain in a way that suggests that he has been exposed to the same kind of torture Welch used with Haynes. Frank is finally brainwashed; he is seen repeating Welch's words, and, later, he sells his heifers - which stand in for his and Emma's lives - and leaves with Haynes and Welch to an unknown destination.

In "Hell in the Heartland," Una Chaudhuri refers to the same significance of the heifers in The God of Hell, stating that "For Frank, his animals provide a rapture of participation in an agrarian world that is fast disappearing, taking with it the stability and certitudes once signified by the homestead, the ranch, the little house on the prairie" (52). This disturbing ending comes as a sharp contrast to the play's idyllic beginning; selling the heifers signals the end of tranquility and assurance that used to be the foremost qualities of the utopian existence which Frank and Emma stand for, giving way to a dystopic kind of life, one dominated by obscurity, uncertainty, oppression and violence.

There have been studies that examined the post-September 11 policies of the American Administration in relation to the concept of Utopia/Dystopia. For example, in his article, "The Deterritorialized Wars of Public Safety" (2004), Allen Feldman calls the United States' campaigns against terrorism in Iraq and Afghanistan "wars of dystopia" (73). He describes the American policy of the time as a "political fantasy" that "promoted the ahistorical polarities of civilization/barbarism" (73). Feldman elucidates his conception, writing that the World Trade Center "was eulogized as a violated Utopian space" that was "threatened by an invisible, infiltrating menace" (73). Hence, the focus has been placed on the perception of the United States as a utopia jeopardized by external threat.

The contribution sought in the present research, conversely, is the examination of the connection between post-September 11 policies of the United States and the idea of Utopia/Dystopia from the point of view of the discord between the post-September 11 American nationalist discourse and the actual American political practices, in an attempt to reveal this discourse as laying the foundation of a dystopia in the American society, despite attempting to draw an image of this society as a utopia. This perspective shares Chad Walsh's premise that "dystopia is most often social planning that backfires and slides into nightmare" (137). In the following analysis of Shepard's play, the life of the American people will figure as a dystopia created-ironically-in the course of the Administration's attempt to establish security, loyalty and solidarity, the 
bases of a utopia from the government's point of view. Frank's final appearance on stage is an instance of the "nightmarish" existence where the individual's freedom is crushed, and his sole function is reduced to complete obedience to and support for the state. Walsh identifies such a condition as one of the main elements of dystopia: "by weakening the sense of individual identity, [it becomes] more likely that the average man will merge his own frail identity with the social whole" (143). In "The Nature of 'Outsider Dystopias," Sharon Stevenson expresses a similar view, asserting that in dystopian literature, the utopia intended by oppressive regimes results in dispossessing the human being of his freedom, of his dignity:

the evil in a dystopia is usually a faceless, all-encompassing state, bureaucracy, or belief system that annihilates or restricts some set of values the readers believe are indispensable to both their own and the characters' ability to function as fully dignified human beings. (131)

Axel Honneth's theory about justice provides the conceptual framework of this study, as it offers an in-depth examination of the core values at stake in the play. Honneth's definitions of justice, a just society, ethical life and mutual recognition will be employed to present a reading of the play as a rewriting of the American nation after the September 11 attacks, as a questioning of the popular image of the United States as the land of freedom and democracy.

In The Struggle for Recognition: The Moral Grammar of Social Conflicts, Honneth develops the foundations of a social theory where he defines justice as the recognition of all members of the society, and describes it as a vital human need. This mutual recognition -as Honneth calls it- is indispensable for the achievement of the basic foundations of identity formation and ethical life, namely self-confidence, self-respect and self-esteem. By self-confidence, Honneth means the capacity to express one's needs and desires without fear of being abandoned as a result. He uses the term self-respect to refer to the individual's ability to assert and defend his claims as well as viewing oneself as entitled to the same treatment as every other person. Self-esteem, as used by Honneth, involves as sense of what distinguishes a person from others, which by implication- must be something valuable, as it underscores the individual's uniqueness. Honneth asserts that certain cultural conditions, namely exclusion, insult and degradation, are violations of self-confidence, self-respect and selfesteem, because such conditions are essentially experiences of disrespect. It is the state's failure to meet its subjects' moral expectations, he adds, that results in the absence of justice. 
The ideals that Honneth calls for are the basis of a utopian city-state, typically characterized by "the institutions and policies [being] entirely governed by reason" as opposed to communities "divided by self-interest and greed for power and riches" ("More's Utopia"). In this study, The God of Hell will be presented as supportive of Honneth's political theory in the sense that it portrays a dystopic kind of existence where all the elements that contribute to a just society and an ethical life - in Honneth's sense - are absolutely obliterated.

It will be further argued that this dystopic image of the American society resulted from the nationalist discourse employed forcefully after the September 11 attacks, which makes a brief reference to the concept of nationalism a necessary prelude to this paper. In his famous 1882 lecture "What is a Nation?," French scholar Ernest Renan defines nationhood as a "spiritual principle" founded on "the desire to live together" (10). Renan further emphasizes the significance of the individual in the life of the nation: "a province is its inhabitants and, if anyone in this affair has the right to be consulted, it is the inhabitant" (10). Along the same lines, John Hutchinson examines the emergence of nationalism, underscoring the importance of recognizing and embracing individual differences as the basis of civil life. In "Cultural Nationalism," Hutchinson presents an idealistic view of nationalism, a view that is closely attuned with Honneth's theory with its emphasis on freedom, equality and tolerance. Hutchinson writes that "Nationalism encouraged the rise of a civil society, of an educated citizenry engaged in a diversified "public" sphere in which all could participate no matter what their social, economic, religious status. All nationalists appeal to the nation as ... moulded by human will" (76. Italics mine).

This perception of nationalism, however, does not exist in The God of Hell; it is, in fact, subverted. The nationalist discourse we see in the play reveals a completely opposite perspective, one in which autocracy and coercion figure as the basis of the state, and, consequently, citizens are judged as either loyal patriots - if they embrace the state's policy - or traitors - if they differ with it. It is this tyranny which Shepard refers to, talking about The God of Hell and its relation to the political milieu before the 2004 presidential elections: "What is that show-your-colors mentality about? Fear. The sides are being divided now ... So if you're on the other side of the fence, you're suddenly anti-American. It's breeding fear of being on the wrong side" (qtd. in Shewey par. 7).

The idea that the country is subjected to external threat is the government agent's tool to force the other characters into adopting the Administration's principles. In his preface to Bart Bonikowski's Research on American Nationalism, Paul DiMaggio refers to this strategy in relation to the American nationalist discourse: 
Periods preceding and following major wars ... were characterized by vigorous discussions of national identity and civic obligation ...The convergence of the perceived threat of terrorism after the events of September 11, 2001 with war in the Middle East ... provides fertile terrain for an increasing salient discussion of nationalism, patriotism, collective identity, and civic obligation. (3)

Indeed, in The God of Hell, the characters are coerced to believe that maintaining their country's security is a duty they have to fulfill in only one way, namely by giving up their individuality and abiding by the doctrines propagated by the government, in the name of patriotism.

The few years that followed 9/11 mark a critical point in the history of the United States of America where values such as freedom, justice, dignity, patriotism and solidarity were constantly debated. In its public discourse, the American government powerfully promoted the image of the United States as a nation that respects and nurtures these values. The government strongly endeavoured to emphasize the idea that the freedom to resist was key to maintaining rights: rights are "secured by free dissent" (Bush, Jr. "Second Inaugural Address," par. 11). It was also asserted that freedom is crucial for the attainment of justice: "no justice without freedom" (par. 11). Differences, tolerance and the freedom of expression figured in public discourse as integral to America's political life: "It's one of the great strengths of our democracy that we can discuss our differences openly and honestly, even at times of war" (Bush "War on Terrorism" par. 150).

Here, one can raise a question: with this highly resonating nationalist discourse, is the individual really living in the utopia portrayed by the state? In fact, the actual American political decisions and practices of the time came only to invalidate such discourse. Violations of civil liberties were typical of the American policy of the time. Other nations whose policies were not approved of by the United States were labeled by the latter as terrorists who jeopardized its security, and were, accordingly, penalized. For example, commenting on the invasion of Iraq, President Bush Jr. said "In Iraq, we saw a threat, and we realized that after September the 11th, we must take threats seriously, before they fully materialize" (The First Bush-Kerry Presidential Debate. Italics mine).

Noteworthy is that these violations were by no means limited to what the administration called its enemies. These violations extended to influence the lives of the American people. A close observation of the frequent use of the first person plural pronoun in the above quote sheds light on the government's verbal manipulation. It is trying to convey a kind of unity between the government and 
the people whom it represents, forcefully leading the people into believing that this is what the whole nation actually "saw" and "realized." Criticizing the invasion of Iraq, Chip Pitt and Bryan Long write that this war was "corroding democracy in the United States homeland" ("War, Law and American Democracy"). Indeed, Americans who did not support the "War on Terrorism" launched by the Administration were seen by the regime as enemies; they were excluded as unpatriotic citizens. In the same speech where "the freedom to disagree with each other" was praised by the American President as a feature of the American society, it was made explicit that "You [the American people] are either with us, or you are with the terrorists" ("Address to a Joint Session of Congress and the American People"). Commenting on this policy and on the self-righteous rhetoric of good versus evil, many critics emphasize that "the "war on terrorism' is an ideology of fear and repression that creates enemies and promotes violence rather than mitigating acts of terror and strengthening security. The worldwide campaign has too often become an excuse for governments to repress opposition groups and disregard international law and civil liberties" ("War on Terrorism"). In a milieu where opposing the government's beliefs meant treason, the freedom of thought and the voice of dissent were, consequently, silenced.

With this exclusion, despotism, violence and intolerance, the nationalist discourse of the time led to a dystopia. The God of Hell can be read as a dramatic critique of that experience. Indeed, Shepard presents "an imagined universe in which oppressive societal control and the illusion of a perfect society are maintained through ... totalitarian control" ("Dystopias: Definitions and Characteristics"). The situation portrayed in the play is one where the individual's basic rights of understanding, dignity, freedom of thought and expression, as well as maintaining one's identity are denied. The characters in the play are being tortured - both physically and mentally-by a government agent in an attempt to force them into abiding by the regime's notions, the pretext being maintaining national security. Ironically, this very policy is itself an act of totalitarianism and terrorism.

The God of Hell premiered in New York in 2004. Events which occupied the political foreground at the time - the Abu Ghraib abuse and the US presidential elections - are behind the memorably powerful stage images the play presents. The electrical cord attached to Hayne's genitals is used by Welch as a means of torture as well as humiliation, an image reminiscent of the Abu Ghraib violations. "It's just like holding the leash of a well-behaved dog," Welch says to Emma (Shepard 39). The American flags Welch hangs all around the house is a compelling image of America prior to the elections. Indeed, after September 11 , there was rarely a house in the United States which did not have a flag hung 
on the windows. The use of these stage images makes it feasible to see the play as a sharp criticism of the American Administration's reaction to the traumatic event of September 11, i.e. a criticism of the American foreign policy.

My focus is, however, on the impact of the Administration's practices on the American society itself, on the American people. Commenting on the effect of the war on terror and its rhetoric, Pitt and Long maintain that "This overbroad, preventive, perpetual war sustained by a climate of propagandistic fear and deception ... has led to over-broad changes that seriously undermine centuriesold liberties and the rule of law in ways that will not be easy to reverse" (par. 6).

There is a compelling parallelism between what the agent says in the play and the Administration's rhetoric at that time. For example, the agent's "We're suddenly stung by our duty to a higher purpose" (Shepard 33) echoes President Bush Jr.'s "advancing these ideals [freedom, democracy, human dignity, human rights] was the calling of our time" ("Second Inaugural Address," par. 5). Welch, the government agent, further claims: "We're provoking rebirth!" (Shepard 31).

Yet, both the government representative's actions and the Administration's practices reveal a complete contradiction to these claims. Like the characters in the play, we are shocked into realizing that the "higher purpose" and "the calling of our time" are reduced to totalitarian tactics. This contradiction between word and action, between the language used and the actual reality, reveals where the society Shepard portrays truly stands in relation to Honneth's idea of the just society. This contradiction, furthermore, enhances the dystopic existence Shepard's characters are leading; not only are they denied freedom, acceptance and respect, they are also living in a hypocritical world. Emma, Frank and Haynes are subjected to a kind of deceptive and manipulative rhetoric which they are forced to believe and which totally contradicts the reality.

In the play, when the government agent bluntly expresses the Administration's self-image as the absolute power in the world, we see an unjust dystopic society where the ruler's authority and power are unbounded, which implicitly suggests the total relegation of the will and needs of the individual subjects. When Haynes remarks that Welch should not be in full control of Emma's and Frank's house, i.e. controlling and changing the way they think, Welch answers: "We can do whatever we want ... We're in the driver's seat ... There's no more of that nonsense of checks, and balances. All that red tape ... We're in absolute command now. We don't have to answer to a soul" (31). And, indeed, this is what he achieves; despite suspecting Welch earlier in the play, Frank ultimately, gives in to the former's attempts to indoctrinate him. "He's [Welch's] from the government ... our government ... That means he knows more than us. He's smarter than us. He knows the big picture ... The Enemy. He 
knows who the enemy is," Frank says to Emma who is shocked by Welch's disruption of their life (35).

This points out Welch's role as a carrier of one of the play's central themes. Chaudhuri's "Hell in the Heartland" deals with The God of Hell as a "political allegory" of contemporary America as a land where the government manipulates the people into adopting an ideology whose sole function is to promote the country's foreign policy, a policy which aims primarily at having absolute control of the world. The outcome of this process, according to Chaudhuri, is the "remapping" of the American nation, that is altering the face of the society by obliterating its freedom of thought (54). We see Frank believing Welch's discourse, and, thus, joining the fanatic sector of the society which blindly supports the government's decisions. Similarly, despite his resistance at the beginning, Haynes finally gives in to Welch's command. We infer that he is going to proceed with bomb-making. Emma is the only character who does not change, yet this does not mean that she is safe from Welch's influence. She is seen completely devastated, watching her life completely destroyed. Welch, thus, figures as the agent of this "remapping," encroaching upon the lives of the rest of the characters, permanently changing them (54).

In addition to intellectual coercion, Haynes and Frank are subjected to brutal physical torture at the hands of the government representative. Figuring as one of the fundamental elements in the structure of an unjust society, according to Honneth, physical oppression contributes to the picture of a dystopia where the individual's freedom is tied and $\mathrm{s} / \mathrm{he}$ becomes utterly dominated by another entity. Honneth believes that "every attempt to gain control of a person's body against his or her will ... causes a degree of humiliation," adding that "what is specific to these kinds of physical injury ... is not the purely physical pain but rather the combination of this pain with the feeling of being defencelessly at the mercy of another subject, to the point of feeling that one has been deprived of reality" (Honneth 132). This accurately applies to the experience of Frank who has become too weak and vulnerable to challenge authority and assert his own beliefs.

Emma, on the other hand, manifests more defiance. With suspicion and apprehension, she seeks an explanation to what is going on around her, through posing questions in every scene. Hence, she establishes the interrogative tone of the play. This tone intensifies the feelings of loss, uncertainty and uneasiness, feelings which do not belong in the utopia implicitly promised by Welch.

With the emergence of Welch in her life, Emma feels threatened, her emotional and intellectual space violated. The physical definition of Welch at his first appearance is powerfully reminiscent of the post-September 11 government personnel in a "dark suit with American flag pin in his lapel ... crisp 
white suit, red tie" (Shepard 8). In addition, Shepard introduces him on stage in a manner that brings the ideas of power, domination and dictatorship to the fore: "A man's arm pops into view, dangling a large cookie in the shape of an American flag, with red, white, and blue frosting" (8). Even when Emma expresses her resistance, telling him she is not interested in the cookies, he keeps urging her to take them. "Hold it then. Just take ahold of it and feel its wonderful weight and texture," he tells her (8). As Haynes puts it toward the end of the play, "We're - what they want us to do" (40).

In addition to the "American-made cookies," as Welch calls them, flags are used in the play as a sign of patriotism (8). Welch tries to force Emma to put up "a flag or something to that effect, some sign, some indication of loyalty and pride," noting that without "even one small token in the home" such as a "miniature Mount Rushmore, Statue of Liberty ... We could be anywhere," to which Emma significantly replies: "We're not anywhere" (12. Italics mine). Emma's reply, simple and straightforward as it seems to be, is very suggestive. She expresses real loyalty and love for her country, for the life she leads on her and her husband's farm where "there's no tension ... Everything's quiet and peaceful" (18). To her, this love and attachment to the place where one belongs need no physical or verbal manifestation in order to prove genuine as Welch suggests. Emma's strong attachment to her country is the kind of patriotism which Shepard believes in. Criticizing the showing off of loyalty to one's country, Shepard says: "We're being sold a brand-new idea of patriotism. It never occurred to me that patriotism had to be advertised. Patriotism is something you deeply felt. You didn't have to wear it on your lapel or show it in your window or on a bumper sticker" (qtd. in Shewey par. 6).

In "In the Name of the Nation," Brubaker criticizes the idea of flag-waving, as "associated with intolerance, xenophobia, and militarism, with exaggerated national pride and aggressive foreign policy" (118). Brubaker explores the repulsive hostile aspect of nationalism, when it develops into a policy of exclusion and othering. Brubaker further condemns what he calls the "monopoly" of the "language" and "iconography" of patriotism exercised by one party and imposed on the people: "In the aftermath of the September 11th attacks, ... verbal and visual emblems of nationhood and patriotism have become deeply associated with the fateful decision to frame those attacks in the language of "war' rather than 'crime"" (123). This explains his position that "unspeakable horrors ... have been perpetrated in the name of the nation." (118) A close observation of The God of Hell reveals a similar experience. The government represented by Welch- claims to be the only representative of the truth and, consequently, imposes on the people what to believe and how to express it, using the ideal of patriotism as its tool to manipulate the people. 
This dismissal of difference deprives the characters of self-esteem and the sense of superiority, according to Honneth's theory. Honneth situates esteem in the values of a particular culture. That is, social conditions for self-esteem are determined by a prevailing sense of what is to count as a worthy contribution to the society. Frank and Emma live in a society that excludes and even condemns insurgents. Based on Honneth's theory, such a society remarkably departs from the image of the just society as he envisions it. Thus, instead of the "rebirth" the government representative promises in the play, the characters face destruction, emotional and intellectual annihilation (Shepard 31). Welch's attempt to make Emma express her patriotism in the one particular way he accepts is actually an attempt at "the destruction of personal identity," the foremost feature of dystopias as Martin Kessler puts it in "Orwell and the Perfect State" (568).

Brubaker introduces a definition of patriotism, one which upholds the critical mind of the individual as the basis for true loyalty and love for one's country. Brubaker writes:

Patriotic identification with one's country -the feeling that this is my country, and my government- can help ground a sense of responsibility for ... actions taken by the national government. A feeling of responsibility for such actions does not, of course, imply agreement with them; it may even generate powerful emotions such as shame, outrage, and anger that underlie and motivate opposition to government policies. (121. Italics mine)

With its focus on freedom, this definition makes embracing difference and recognizing the worth of the individual the basis for true patriotism. Hence, this perception of patriotism is very well-suited for Honneth's theory where mutual recognition is an indispensable precondition for the full development of the people's identities and for providing the basis of a just society. Its absence, however, in the world of The God of Hell contributes to the dystopic portrayal of the society depicted.

The play ends with Frank selling his heifers, Welch getting Frank's and Emma's house ready for a "meeting," and Emma standing outside the house ringing the bell but unable to enter. Throughout the play, Frank, Emma and their house stand in for the simple traditional rural American life, a utopia, trying to maintain its values and resist the corruption and degradation ushered in by Welch, the representation of a totally contradictory world view. To choose this ending for his play, Shepard suggests the inability of the people to stand in the face of a destructive policy that sweeps away all the values that had always given strength to that society, namely freedom and multiplicity. The play, it can be 
claimed, ends with the destruction of Emma's and Frank's utopia, of "the world [that] was perfect once," as Frank puts it in the play (Shepard 39).

In The God of Hell, Shepard, thus, presents an alternative image of his country as a land where freedom is more verbally upheld than actually realized, and justice, dignity and freedom are therefore, unattainable. Honneth argues that it is the state's failure to meet its subjects' moral expectations that results in the absence of justice. These moral expectations, according to him, comprise the maintenance of freedom, identity, human dignity and human rights, concepts which are all violated in The God of Hell. In the light of Honneth's idea that inclusion is the only way to meet the claims of recognition and, therefore, establish an ethical life and a just society, it can be asserted that the defeat of Shepard's characters who fail to assert their freedom, to be accepted by society and to maintain their identity is basically a portrayal of the failure of the state itself, of a hypocritical regime that totally excludes and crushes the voice of dissent. The result of this failure is a dystopic society where the individual loses his sense worth, dignity, freedom, peace and identity. The play patently expresses its playwright's vision: "Democracy's a very fragile thing. You have to take care of democracy. As soon as you stop being responsible to it and allow it to turn into scare tactics, it's no longer democracy, is it? It's something else. It may be an inch away from totalitarianism" (qtd. in Shewey par.7).

\section{Works Cited}

Brubaker, Rogers. "In the Name of the Nation: Reflections on Nationalism and

Patriotism." Citizenship Studies. Vol. 8, No. 2 (June 2004), pp. 115-127.

Bush Jr., George W. "Address to a Joint Session of Congress and the American

People."

<http://georgewbush-whitehouse.archives.gov/

news/release/2001/09/20010920-8.html> 20 Sept., 2001. Web. 19 April, 2017.

----. "Second Inaugural Address." National Public Radio $<$ www.npr.org/templates/story/story.php?storyId=4460172President Bush's Second Inaugural Address > 20 Jan., 2005.Web. 26 Oct., 2014.

----. "War on Terrorism." Washington Post <http://www.washingtonpost. com/wp-dyn/content/article/2005/11/30/AR2005113000667.html>

Nov., 2005. Web. 26 May, 2017.

Bush Jr., George W. and John Kerry. "The First Bush-Kerry Presidential

Debate." Commission on Presidential Debates <www.debates.org $>30$ Sept., 2004. Web. 21 June, 2016.

Chaudhuri, Una. "Hell in the Heartland: Mapping Post-Abu Ghraib America in Sam Shepard's The God of hell." Contemporary Drama in English (Mapping 
Uncertain Territories: Space and Place in Contemporary Theatre and drama), Vol. 13 (2006), pp. 49-60.

DiMaggio, Paul. Preface to Research on American Nationalism: Review of Literature, Annotated Bibliography, and Directory of Publicly Available Data Sets by Bart Bonikowski. New York: Russell Sage Foundation, 2008.

"Dystopias: Definitions and Characteristics." <http://www.readwritethink. org/files/resources/lesson_images/lesson926/DefinitionCharacteristics. pdf > Web. 1 Sept., 2016

Feldman, Allen. "Deterritorialized Wars of Public Safety." The International Journal of Social and Cultural Practice Vol. 48, No. 1 (Spring 2004), pp. 73 80. Web. 23 Jan., 2016.

Honneth, Axel. The Struggle for Recognition: The Moral Grammar of Social Conflicts. Trans. Joel Anderson. Cambridge: Polity Press, 1995.

Hutchinson, John. "Cultural Nationalism." The Oxford Handbook of the History of Nationalism, ed. John Breuilly. Oxford: Oxford U P, 2013, pp. 75-94.

Kessler, Martin. "Orwell and the Perfect State: A Study in Disillusionment as Reflected in Orwell's Nineteen Eighty-Four and Huxley's Brave New World." Political Science Quarterly Vol. 72, No. 4, (Dec., 1957), pp. 565577.

"More's Utopia." Encyclopaedia Britannica. <www.britannica.com/ topic/utopia> Web. 15 June, 2016.

Pitt, Chip, and Bryan Long. "War, Law and American Democracy." Open Democracy <https://www.opendemocracy.net/democracy-american power/war_law_4028.jsp> 24 Oct., 2006. Web. 26 Oct., 2014.

Renan, Ernest. "Qu'est-ce qu'une nation?" ("What is a Nation?"), trans. Ethan Rundell. Lecture delivered at the Sorbonne on March 11th, 1882. Paris: Presses-Pocket, 1992.

Shepard, Sam. The God of Hell. New York: Dramatists Play Service, 2005. Shewey, Don. "Patriot Acts." The Village Voice. <https://www.villagevoice. com/2004/11/09/patriot-acts/> 9 Nov., 2004. Web. 31 May, 2017.

Stevenson, Sharon. "The Nature of 'Outsider Dystopias': Atwood, Starhawk, and Abbey." The Utopian Fantastic: Selected Essays from the Twentieth International Conference on the Fantastic in the Arts. Eds. Martha Bartter and Thomas J. Morrissey. Westport: Praeger, 2004. 129-136.

Walsh, Chad. From Utopia to Nightmare. New York: Harper \& Row, 1962. "War on Terrorism." < https://www.globalpolicy.org/war-on-terrorism. html> Web. 17 Oct., 2014. 